V.V. Shevchenko, A.N. Minko, A.V. Strokous

\title{
ANALYSIS OF ELECTROMAGNETIC VIBRATION FORCES IN THE ELEMENTS OF THE TURBOGENERATOR STATOR FASTENING TO THE CASE IN NON-NOMINAL OPERATION MODES
}

Purpose. The purpose of the paper is to determine the value of additional electromagnetic forces (EMF) that are created by the fluxes of scattering of the back of the turbogenerator (TG) stator core in the elements of its fastening to the case when operating in non-nominal modes according to the vibration control data. Methodology. The paper used the theory of electromagnetic fields, the method of polynomial approximation, mathematical modeling in the MathCAD-2000 professional package and the provisions of the general theory of electrical machines. Results. Analytical and numerical calculations of additional EMF values are performed, which were created by the leakage fluxes of the back of the stator core in the elements of fastening of the TG to the case when operating in non-nominal modes, which is determined by the need for night unloading of the power system. The values of these TG forces are established with a change in the output and consumption of reactive power and with a change in voltage. Originality. For the first time for TGs operating in non-nominal modes, the estimation and calculation of additional EMF in the elements of the TG core fastening to the case are carried out, which are created by the leakage fluxes of the back of the stator core and supplement the action of the basic EMF. The definition of these forces is relevant, because turbogenerators of TPPs in Ukraine with a capacity of 200-300 MW are maneuvering capacities and solve the problem of maintaining the power factor of the power system. Practical value. It was found that if the TGs often operate in non-nominal modes, the wear of the stator core fastening systems to the case is more significant than in the case of their operation only in nominal modes. The obtained data will allow to more accurately determine the scope of repair work, draw up schedules for their implementation, determine the locations of the sensors for monitoring, and can be used at the design stage of new machines. References 6, tables 2, figures 2.

Key words: turbogenerator, load mode, non-nominal mode, electromagnetic force, reactive power, stator core fastening unit.

Целью статьи является определение величины дополнительных электромагнитных сил (ЭМС), которые создаются потоками рассеяния спинки сердечника статора турбогенератора (ТГ) в элементах его крепления к корпусу при работе в неноминальных режимах по данным вибрационного контроля. Методика. В работе использовали теорию электромагнитных полей, метод аппроксимация полиномами, математическое моделирование в пакете МатһCAD2000 professional, положения общей теории электрических машин. Результаты. Выполнень аналитические и численные расчеты дополнительных величин ЭМС, создаваемых потоками рассеяния спинки сердечника статора в элементах крепления ТГ к корпусу при работе в неноминальных режимах, что определяется необходимостью ночных разгрузок энергосистемы. Установлены значения этих сил ТГ при изменении выдачи и потребления реактивной мощности и при изменении напряжения. Научная новизна. Впервые для ТГ, работающих в неноминальных режимах, выполнены оценка и расчет дополнительных ЭМС в элементах крепления сердечника ТГ к корпусу, которые создаются потоками рассеяния спинки сердечника статора и дополняют действие основных ЭМС. Определение этих усилий актуально, т.к. турбогенераторы ТЭС Украины мощностью 200-300 МВт являются маневренными мощностями и решают задачу поддержания коэффициента мощности энергосистемы. Практическое значение. Было установлено, что если ТГ часто работают в неноминальных режсимах, износ систем крепления сердечников статора к корпусам более значителен, чем в случае их работы только в номинальных режимах. Полученные данные позволят более точно определять объемы проведения ремонтных работ, составлять графики их проведения, определять места установки датчиков контроля, могут быть использованы на этапе проектирования новых машин. Библ. 6, табл. 2, рис. 2.

Ключевые слова: турбогенератор, режим нагрузки, неноминальный режим, электромагнитная сила, реактивная мощность, узел крепления сердечника статора.

Introduction. Currently, there is a high degree of aging of the park equipment of thermal power plants (TPPs). Therefore, taking into account the national economic situation, the strategic task for Ukraine is to extend the life and increase the reliability of long-term operating turbogenerators (TGs), improve their maintenance and optimize the costs of upgrading and technical re-equipment of TPPs and nuclear power plants (NPPs).

One of the most effective solutions to these challenges is to improve the quality, implementation and development of new ones, as well as to improve existing methods for diagnosing TG, which ensure timely and complete detection of defects (including at an early stage of their development), as well as the completeness and quality of their elimination. The reliability of the TG and its physical life is largely determined by the technical state of the stator core, including the system of its fastening to the case. Reliable execution of the fastening unit provides the necessary level of core rigidity, vibration isolation of the stator case and the foundation from vibrations caused by electromagnetic forces (EMFs) of the active zone. In turn, a reliable fastening system protects the stator core from external vibrations transmitted from the foundation through the supports and sliding bearings to the case of the TG, which is especially important in maneuvering operation modes $[1,2]$.

The goal of the paper is determination of the value of additional EMFs that are created by the leakage fluxes of the back of the stator core of the turbogenerator in the elements of its fastening to the case when operating in non-nominal modes according to the vibration control data.

The main material of the study. According to the statistics collected by the operating personnel of power (c) V.V. Shevchenko, A.N. Minko, A.V. Strokous 
plants, the state of the cases and cores of TG stators, which for a long time operated in non-nominal modes (at a load of $70,50,30 \%$ of the nominal) on TPP units, it was found that compared to the TGs that operated only in nominal modes, the value of vibration is higher. Vibration of the stator case is monitored periodically, and vibration measurement of the fastening elements of the active steel of the stator core to the frame of the case is carried out very rare, only in cases of obvious symptoms of deterioration of their vibration state or in the unsatisfactory state of the stator steel structures (contact corrosion, damage to attachment points, etc.), i.e. already in the presence of a defect. At the same time, it is known from the operating experience that the volume and efficiency of repair work depends on the stage of defect development.

Conducting a vibration examination of the core fastening system is associated with certain difficulties, which is determined by the need to take into account the design of the hydrogen or air exhaust assemblies, the terminals of the measuring systems from the case through gas tight fingers and other elements, the presence of sensors inside the generator. But, if you install the vibration monitoring system of the case in advance, it is possible to detect defects in time, which can lead to serious damages and require expensive repairs, and in some cases a complete replacement of the generator.

Usually the vibration spectrum obtained from vibration signals taken from the case of the operating generator includes a fundamental harmonic with frequency of $100 \mathrm{~Hz}$ and a number of harmonic components that are multiples of the fundamental harmonic. Thus, when servicing the turbogenerators of the unit No. 4 of the Gusinoozerskaya TPP (2014), unit No. 1 of the Gomel TPP-2 (2011, 2012), unit No. 15 of the Luganskaya TPP (2014) and unit No. 3 of the Zuevskaya TPP (2013), measurements of the vibrations of the stator cases were performed. It was found that in modes other than nominal, the vibration was maximum, especially in the middle sections of the cases. Table 1 shows the data of tests of the stator case of the turbogenerator ТГВ-300-2У3 of the block № 3 of the Zuevskaya TPP. Fig. 1 shows the layout of the control sensors on the left side «L».

The sensors $1 \mathrm{R}-9 \mathrm{R}$ on the right are arranged symmetrically.

Table 1

Stator case vibration of the ТG ТГВ-300-2У3 of the unit No. 3 of the Zuevskaya ТРP

\begin{tabular}{|c|c|c|c|c|c|c|c|c|c|c|c|c|c|c|c|c|c|c|}
\hline \multirow{3}{*}{ Power of the TG } & \multicolumn{18}{|c|}{ Vibration value, $2 \mathrm{~A}, \mu \mathrm{m}$} \\
\hline & \multicolumn{18}{|c|}{ Point No. } \\
\hline & $1 \mathrm{~L}$ & $2 \mathrm{~L}$ & $3 \mathrm{~L}$ & $4 \mathrm{~L}$ & $5 \mathrm{~L}$ & $6 \mathrm{~L}$ & 7Л & $8 \mathrm{~L}$ & $9 \mathrm{~L}$ & $1 \mathrm{R}$ & $2 \mathrm{R}$ & $3 R$ & $4 \mathrm{R}$ & $5 \mathrm{R}$ & $6 \mathrm{R}$ & $7 \mathrm{R}$ & $8 \mathrm{R}$ & $9 \mathrm{R}$ \\
\hline $\begin{array}{l}P=288 \mathrm{MW} \\
Q=60 \mathrm{MVAr}\end{array}$ & 10 & 13 & 11 & 23 & 33 & 26 & 25 & 40 & 26 & 19 & 28 & 17 & 41 & 48 & 40 & 39 & 47 & 38 \\
\hline $\begin{array}{l}P=220 \mathrm{MW} \\
Q=52 \mathrm{MVAr}\end{array}$ & 11 & 15 & 11 & 26 & 34 & 27 & 29 & 42 & 29 & 23 & 29 & 16 & 43 & 51 & 43 & 41 & 53 & 46 \\
\hline $\begin{array}{l}P=154 \mathrm{MW} \\
O=52 \mathrm{MVAr}\end{array}$ & 15 & 15 & 9 & 28 & 37 & 31 & 31 & 45 & 33 & 28 & 34 & 14 & 49 & 59 & 47 & 47 & 57 & 50 \\
\hline
\end{tabular}

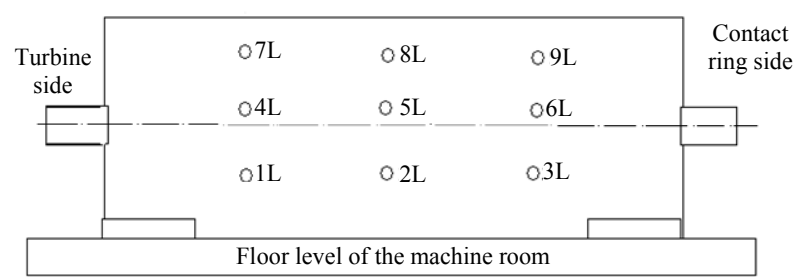

Fig. 1. The location of the vibration measurement points on the left side of the TG case (if viewed from the side of the contact rings)

During investigations it was also noted the weakening of pressing of the laminated packages and the more frequent destruction of the stator winding insulation of the slotted and frontal parts, the destruction of the stator core fastening system to the case [3].

To determine the reasons for the increase in vibration in non-nominal modes, we consider changes in the action of eddy currents, which are induced in the stator core and in the elements of its fastening to the case of the TG. These currents, which are induced by scattering fluxes in the elements of the system of fastening the laminated stator core to the case, and, consequently, the value of the electromagnetic forces acting on the clamp prisms of the TG, depend on the degree of saturation of the core back. The value of the flux of scattering per unit surface (the flux that is displaced from the core into the fastening zone to the case) can be represented $[1,2], \mathrm{Wb} / \mathrm{m}$ :

$$
\Phi_{d i s}=\frac{\mu_{0} \cdot H_{S} \cdot \tau}{\pi} \cdot\left[1+\left(\frac{R_{S}}{R_{k}}\right)^{2 p}\right] \cdot\left[1-\left(\frac{R_{S}}{R_{k}}\right)^{2 p}\right]^{-1},
$$

where $\mu_{0}=4 \pi \cdot 10^{-7} \mathrm{H} / \mathrm{m}$ is the magnetic constant; $H_{S}$ is the amplitude of the tangential component of the magnetic field strength on the surface of the stator back, $\mathrm{A} / \mathrm{m} ; R_{S}$ is the outer radius of the stator core back, $\mathrm{m} ; \tau$ is the pole division, $\mathrm{m} ; R_{k}$ is the inner radius of the stator case, $\mathrm{m} ; 2 p$ is the number of poles.

Thus, the flow displaced from the core is directly proportional to the magnetic field strength in the back of the core, which in turn depends on magnetic flux density, i.e. from the operating mode of the generator [3].

When the operating mode changes, the temperature of the active and structural parts of the stator changes, which affects their linear dimensions. The coefficient of linear expansion of steel is $0.12-0.15 \mathrm{~mm}$ per $1{ }^{\circ} \mathrm{C}$ [4]. If the temperature of the stator core is increased by $30{ }^{\circ} \mathrm{C}$, its linear dimensions will increase only by $0.04 \%$ of the initial value. Therefore, the thermal 
expansion of the linear dimensions of the prisms, core packages, and the fastening system can be neglected. Also in calculations it is possible to neglect the influence of heating on the resistance of the circuits of the closure of eddy currents [5].

The permissible non-nominal modes of operation of the TG are regulated by the instruction manual and are determined from the diagram of permissible loads [5]. Therefore, we select the active power $(P)$, reactive power $(Q)$ and the line voltage of the stator winding $\left(U_{s}\right)$ to characterize the operating modes. Let us determine the analytical relationship of the indicated parameters with the value of the EMF acting on the fastening elements. The sequence of the analytical calculation of electromagnetic forces is described in detail in [2].

The amplitude of magnetic flux density on the outer line of the back of the stator core can be determined:

$$
B_{s}=\frac{E_{r}}{2 \cdot \sqrt{2} \cdot \pi \cdot f \cdot \omega_{s} \cdot k_{0} \cdot S_{s}} \cdot k_{c}
$$

where $f$ is the network current frequency; $k_{0}$ is the winding factor; $\omega_{s}$ is the number of turns of stator winding; $S_{s}$ is the stator back section; $k_{c}$ is the coefficient that characterizes the uneven distribution of magnetic flux density in the stator back; $E_{r}$ is the electromotive force, which is induced by the magnetic fluxes of the scattering of the back of the stator core in the clamp prisms in the non-nominal operating modes:

$$
E_{r}=\sqrt{\left(\frac{U_{s}}{\sqrt{3}}+x_{\sigma} \cdot I_{s} \cdot \cos \left(\frac{\pi}{2}-\varphi\right)\right)^{2}+\left(x_{\sigma} \cdot I_{S} \sin \left(\frac{\pi}{2}-\varphi\right)\right)^{2}} .
$$

The angle between the stator voltage and current vectors, as well as the stator current, A:

$$
\varphi=\arccos \left(\frac{P}{\sqrt{P^{2}+Q^{2}}}\right) ; \quad I_{s}=\frac{1}{U_{s}} \cdot \sqrt{\frac{P^{2}+Q^{2}}{3}} .
$$

Taking into account (3), the value of the resulting electromotive force in the stator back and in the elements of its fastening to the case:

$E_{r}=\sqrt{\left(\frac{U_{s}}{\sqrt{3}}+\frac{x_{\sigma}}{U_{s}} \cdot \sqrt{3 \frac{P^{2}+Q^{2}}{3} \cdot \cos \left(\frac{\pi}{2}-\arccos \left(\frac{P}{\sqrt{P^{2}+Q^{2}}}\right)\right)}\right)^{2}+\left(\frac{x_{\sigma}}{U_{s}} \cdot \sqrt{\frac{P^{2}+Q^{2}}{3}} \cdot \sin \left(\frac{\pi}{2}-\arccos \left(\frac{P}{\sqrt{P^{2}+Q^{2}}}\right)\right)^{2}\right.}$

When calculating the values of the magnetic field strength in the back of the core and the clamp prisms, magnetic flux density in the surface layer of the active steel, the magnetization characteristics of the relevant materials are used, which are selected from the tables [5], but to solve the problem it is advisable to present them in the form of functional dependencies.

The amplitude of the magnetic field strength on the surface of the back of the stator core is related to the magnetic flux density value by a nonlinear dependence and in the range of inductions 0.6 to $1.7 \mathrm{~T}$ is approximated with sufficient accuracy by a polynomial of the 6th degree:

$$
H_{s}=f\left(B_{s}\right)=\sum_{n=0}^{6} h_{n} \cdot B_{s}^{n} .
$$

We determine the amplitude of the magnetic field strength on the upper line of the back of the stator core, then we find the values of the magnetic flux linked to the contour of the fastening elements and the back surface, and determine the electromotive forces induced by it on the prisms. When calculating the resistance of the contour of the formation of the eddy current $Z_{k}$, it must be taken into account that the resistance of the prism $Z_{p}$ and the end package depends on the degree of saturation of the material.

However, taking into account that the resistance of the eddy current shortage contour is approximately $80 \%$ determined by the resistance value of the fastening elements, in the further calculations the resistance of the end core packets is assumed to be constant, the effect of saturation of the active steel on the resistance value of the contour $Z_{k}$ is neglected.

The relative magnetic permeability of the prism material $\mu_{p}$ also depends nonlinearly on the magnetic field strength and can be represented as:

$$
\mu_{p}=\sum_{n=0}^{6} m_{n} \cdot H_{s}^{n} .
$$

The change in the magnetic permeability $\mu_{p}$ on the magnetic field strength for the steel St 3, of which the prisms of the fastening are made, is considered in the interval $100-1250 \mathrm{~A} / \mathrm{m}$.

The magnetic flux density amplitude, which corresponds to the value of the magnetic field strength $H_{S}$ on the surface of the back of the core, can be represented as:

$$
B_{s \cdot \max }=\sum_{n=0}^{3} b_{n} \cdot H_{s \cdot \max n} \text {. }
$$

When examining the dependence of the EMF value in different modes, we change the value of one of the parameters $\left(P, Q, U_{S}\right)$ within the limits determined by the power diagram and a typical operating instruction, while the other two parameters do not change.

To carry out the calculations, we introduce the dimensionless quantity $\varepsilon_{N}$, which is the ratio of the EMF changes to the change in physical quantities $\left(P, Q, U_{S}\right)$ in one of the non-nominal modes $N: 70,50$ and $30 \%$ of the generator load from the nominal $(100 \%)$ :

$$
\varepsilon_{N}=\frac{\left(F_{B}-F_{N}\right) / F_{b}}{\left(N_{B}-N_{N}\right) / N_{b}},
$$

where $N_{B}, N_{N}, N_{b}$ are the upper boundary, lower boundary and base values of the selected parameter $N\left(P, Q\right.$ or $\left.U_{S}\right)$, depending on the mode of operation of the TG; $F_{B}, F_{N}, F_{b}$ are the upper boundary, lower boundary and base values of the EMF.

We accept changes in the values of the parameters that characterize the changes in the modes $\left(P, Q, U_{S}\right)$ :
1) $P_{N}=0 \mathrm{MW}, P_{B}=P_{b}=300 \mathrm{MW}$;
2) $Q_{N}=-80 \mathrm{MVAr}, Q_{B}=Q_{b}=186 \mathrm{MVAr}$;
3) $U_{N}=0.95 \mathrm{kV}, U_{B}=U_{b}=U_{s N}=20 \mathrm{kV}$. 
To verify analytically obtained results, we solve the problem also by numerical methods on the developed mathematical model using the MathCAD2000 Professional package. We study the fastening element (prism), which has been in operation for a long time, in connection with which the metal was worked out: the dimensions of the side gaps of the prism fastening are taken to be $0.435 \mathrm{~mm}$ (data obtained on turbogenerator that operates on the block No. 2 of the Zmievskaya TPP, [6]).

We perform the expansion of the distribution of EMF, its radial and tangential components in Fourier series:

$$
F(\theta)=F_{\cos t}+\sum_{v=1}^{N} F_{v \cdot m} \cdot \sin (v \theta)+\sum_{v=1}^{N} F_{v \cdot m} \cdot \cos (v \theta),
$$

where $\theta$ is the load angle of the TG, electrical degrees; $v$ is the harmonic number; $F_{v . m}$ is the amplitude of the $v$-th harmonic of the EMF:

$$
F_{v \cdot m}=\sqrt{\left(F_{v \cdot m}^{s}\right)^{2}+\left(F_{v \cdot m}^{c}\right)^{2}}, \mathrm{~N}
$$

$\varphi_{v}$ is the phase of the $v$-th harmonic of the EMF

$$
\varphi_{v}=\operatorname{arctg}\left(\frac{F_{v . m}^{c}}{F_{v . m}^{S}}\right),
$$

where $F_{v . m}^{s}, F_{v . m}^{c}$ are the coefficients of the Fourier series for odd and even harmonic components of the $v$-th order, varying from 1 to $v$.

The results of calculating the EMF induced by eddy currents in the stator core fastening elements to the case, obtained analytically and numerically for various operating modes of the TG, are given in Table 2 and in Fig. 2.

Comparison of the results of analytical calculations and the results obtained by numerical methods (Table 2 , Fig. 2) allows us to conclude that the results obtained are fairly close. This confirms the reliability of the calculations performed.

\begin{tabular}{|c|c|c|c|c|c|c|c|c|}
\hline \multicolumn{3}{|c|}{ Active power influence } & \multicolumn{3}{|c|}{ Reactive power influence } & \multicolumn{3}{|c|}{ Voltage influence } \\
\hline \multirow{2}{*}{$\begin{array}{c}P, \\
\text { MW }\end{array}$} & \multicolumn{2}{|c|}{$\begin{array}{l}\text { Value of the EMF first harmonic } \\
\text { amplitude, } N\end{array}$} & \multirow{2}{*}{$\begin{array}{l}Q, \\
\text { MVAr }\end{array}$} & \multicolumn{2}{|c|}{$\begin{array}{l}\text { Value of the EMF first harmonic } \\
\text { amplitude, } N\end{array}$} & \multirow{2}{*}{$\begin{array}{l}U_{S} \\
\mathrm{kV}\end{array}$} & \multicolumn{2}{|c|}{$\begin{array}{c}\text { Value of the EMF first harmonic } \\
\text { amplitude, } N\end{array}$} \\
\hline & $\begin{array}{l}\text { Analytical } \\
\text { calculation }\end{array}$ & $\begin{array}{l}\text { Numerical } \\
\text { calculation }\end{array}$ & & $\begin{array}{l}\text { Analytical } \\
\text { calculation }\end{array}$ & $\begin{array}{l}\text { Numerical } \\
\text { calculation }\end{array}$ & & $\begin{array}{l}\text { Analytical } \\
\text { calculation }\end{array}$ & $\begin{array}{l}\text { Numerical } \\
\text { calculation }\end{array}$ \\
\hline 0 & 104.8 & 179 & -80 & 107.3 & 163.6 & 19 & 132.4 & 173.7 \\
\hline 150 & 141.5 & 179 & 0 & 115.7 & 174.2 & 19.5 & 135 & 185 \\
\hline 100 & 145.2 & 189 & 186 & 145.2 & 189 & 20 & 145.2 & 189 \\
\hline$\varepsilon_{N}$ & 0.03 & 0.053 & $\varepsilon_{Q}$ & 0.183 & 0.094 & $\varepsilon_{P}$ & 1.763 & 1.619 \\
\hline
\end{tabular}

The results of calculating the EMF, acting on the elements of fastening the stator core to the case, obtained analytically and numerically for various modes of operation of the TG
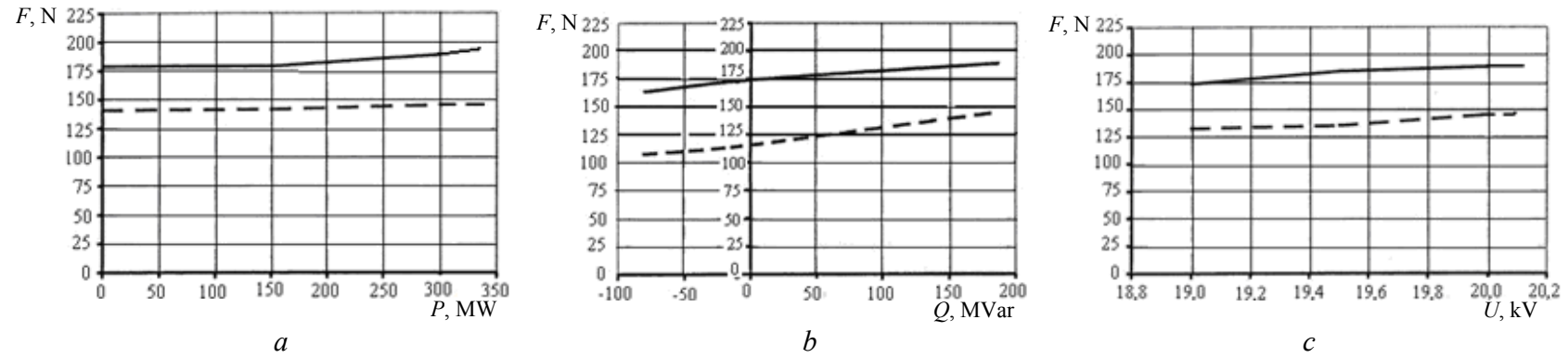

Fig. 2. Dependence of the electromagnetic forces acting on the stator core fastening system to the case on the active power $(a)$, reactive power $(b)$ and stator voltage $(c)$ for various operating modes of the turbogenerator by analytical and numerical methods ( - - - data of analytical calculation; — data obtained by numerical methods)

\section{Conclusions.}

1. The results of analytical and numerical calculations showed that in nominal operating modes of the TG (within the load diagram), the value of the EMF acting on the stator core fastening elements varies little. However, when calculating EMF in non-nominal modes, its change is significant. Thus, for a TG with a power of $300 \mathrm{MW}$, the maximum change in EMF was observed when the reactive power was changed from the largest value (+186 MVAr) to the limiting value of the reactive power consumed (-80 MVAr), which is $13 \%$ (based on the results of numerical calculations).

2. Quantitative characteristics of the change in EMF are obtained depending on the value of active $P$, reactive power $Q$ and on the voltage of the stator $U_{S}$. It is established that under non-nominal operating modes of the TG, the change in the value of these forces is practically independent on the active and reactive power: when $P$ and $Q$ change by $1 \%$, the change in EMF is only hundredths and tenths of a percent, respectively. The dependence of EMF on voltage is more significant, it is quadratic (with a change of $U_{S}$ by $2 \%$, EMF increases by approximately $4 \%$ ).

3. When operating the TG in non-nominal modes, the wear of the TG stator core fastening system to the case is more significant than when operating in nominal modes. This should be taken into account when installing sensors for monitoring the status of the TG in on-line mode, when drawing up schedules for carrying out repairs and determining their volumes.

\section{REFERENCES}

1. Vaskovskyi Yu.M., Melnyk A.M. The electromagnetic vibration disturbing forces of turbogenerator in maneuverable 
operating conditions. Technical Electrodynamics, 2016, no.2, pp. 35-41. (Ukr). doi: 10.15407/techned2016.02.035.

2. Kuznetsov D.V. Investigation of electromagnetic forces acting on the coupling prisms of the stator core of the turbogenerator. Electricity, 2006, no.10, pp. 42-48. (Rus).

3. Stepanov A., Sikora R. Modelirovanie elektromagnitnyh polej v elektricheskih ustrojstvah [Modeling of electromagnetic fields in electrical devices]. Kiev, Tehnika Publ., 1990. 188 p. (Rus).

4. Griscenko M, Vitols R. Stator core vibration and temperature analysis of hydropower generation unit at $100 \mathrm{~Hz}$ frequency. Proceedings of 14th International Scientific Conference Engineering for Rural Development. 20-22 May, 2015. Jelgava, Latvia, pp. 383-388.

5. Shevchenko V.V., Strokous A.V. Forecasting the operating resource of turbogenerators on vibration control data. Norwegian Journal of development of the International Science, 2017, vol.1, no.10, pp. 78-83. (Rus).

6. Minko A.N., Gordienko V.Yu. Turbogenerators with the optimal mass-size parameters in place of the exhausted resources without destroying the original foundation. Energetic and electrification, 2011, no.6, pp. 37-42. (Rus).

Received 10.05.2018

V.V. Shevchenko ${ }^{1}$, Candidate of Technical Science, Associate Professor,

A.N. Minko ${ }^{2}$, Candidate of Technical Science,

A.V. Strokous ${ }^{1}$,

${ }^{1}$ National Technical University «Kharkiv Polytechnic Institute»,

2, Kyrpychova Str., Kharkiv, 61002, Ukraine, phone +380 504078454 ,

e-mail: zurbagan8454@gmail.com, anton220579@gmail.com

${ }^{2}$ Private Scientific and Production Company «Ankor-

Teploenergo»,

19, Kirgizska Str., build 1, Kharkiv, 61105, Ukraine, phone+38097 7924889, e-mail: alexandr.minko@i.ua

How to cite this article:

Shevchenko V.V., Minko A.N., Strokous A.V. Analysis of electromagnetic vibration forces in the elements of the turbogenerator stator fastening to the case in non-nominal operation modes. Electrical engineering \& electromechanics, 2018, no.5, pp. 29-33. doi: 10.20998/2074-272X.2018.5.05. 